\title{
RESEARCH PAPER \\ Growth modeling of castrated Brahman males raised in tropical conditions and born in different seasons
}

\author{
José A. Miguel ${ }^{1}$, Sandy J. Melendez ${ }^{2}$, Begoña Asenjo ${ }^{1}$, Luis M. Bonilla ${ }^{1}$, and \\ Jesús Ciria \\ ${ }^{1}$ Universidad de Valladolid, Escuela de Ingenierías Agrarias de Soria, Campus Universitario s/n, \\ 42004-Soria, Spain. \\ ${ }^{2}$ Universidad Centroccidental Lisandro Alvarado, Barquisimeto, Estado de Lara, 87220, Venezuela.
}

\begin{abstract}
J.A. Miguel, S.J. Melendez, B. Asenjo, L.M. Bonilla, and J. Ciria. 2012. Growth modeling in castrated Brahman males raised in tropical conditions depending on the time of birth. Cien. Inv. Agr. 39(2): 279-288. In this paper, parameters that describe growth, as a function of the season in which they were born (dry or rainy), are presented for males of the for males of the Brahman breed that were castrated at birth and raised in their native environment in the intense system of the Llano Venezolano. Data are presented for 1,478 Brahman males that were castrated at birth. Of these, 750 were born in the months of June and July (the rainy season) and 728 were born in January and February (the dry season). The animals born during the dry season were heavier up until the beginning of the fattening period; after weaning, the greatest average daily weight gain coincided in both groups during rainy periods when the pasture production was greater. When comparing the observed weights with the estimates, the Brody model was better at estimating the actual weight of the animals at birth, weaning and maturity in both seasons of birth. The Gompertz, Bertalanffy, Richards and Logistic models overestimated the weights of the animals at birth and at the end of the fattening period; however, they underestimated the weights at weaning and maturity for both birth seasons. Regarding the birth season, no differences were found in the estimated maturation rate for any of the models, although there were differences among the models for the same season of birth.
\end{abstract}

Key words: Bertalanffy model, Brahman cattle, Brody model, Gompertz model, growth curves, logistic model, Richards model.

\section{Introduction}

The Llanos Venezolanos comprise areas of low savannah, which include the Apure and Orinoco river basins and represent $29 \%$ of the total surface area of Venezuela. The vegetation in this region is characterized by dry tropical forests, and the

Received March 1, 2011. Accepted October 20, 2011. Corresponding author: jangel@agro.uva.es soil has limitations in terms of natural fertility. Regarding climate, there are two well-defined climactic seasons: rainy (May-November), during which the majority of the annual precipitation occurs $(1700 \mathrm{~mm})$ along with a high average temperature $\left(27^{\circ} \mathrm{C}\right)$ and relative humidity $(80 \%)$, and the dry season (December to April), during which the relative humidity is lower (65\%). Important differences in the growth of animals born in either of these seasons exist; fundamentally, this 
is due to a greater incidence of disease (primarily in younger animals) related to the high relative humidity and a difference in the production of pastures (quantity and quality) with respect to the different moisture indexes.

Large pasture areas in the Llanos Venezolanos are occupied by different sized herds of cattle; among these are the Brahman and its crossbreeds of bos indicus origin; primarily, these include Nelore, Gyr and Guzerá, with the Brahman supplying the major genetic proportion of the beef produced in Venezuela. In 2008, a total of 1,732,493 head of beef cattle were butchered in Venezuela, and 30\% of these were imported from Brazil and Colombia. Beef consumption reached $19.3 \mathrm{~kg}$ per inhabitant in 2008 (Miguel et al., 2010).

One common practice in meat-producing systems in Venezuela involves the castration of males at birth, which causes them to have a calmer temperament and facilitates reproductive control over the herds. This also eliminates some undesirable attributes in the meat because the animals are butchered at a later age (31 to 33 months). In intensive meat-producing systems, the calves remain with their mothers until 6-8 months of age when they are weaned to be fed on the pasture during the growth stage (16 months) and the fattening stage (12 months); this practice is based on the abundant pasture found in these tropical zones. At the same time, the calves receive a small concentrated dietary supplement in the form of commercially prepared feed. The animals are slaughtered when they reach a live weight of approximately 480 to $500 \mathrm{~kg}$ at approximately 3 years of age.

Mathematical models for animal growth facilitate an objective comparison of growth among different populations. The evolution of body weight over time allows for the establishment of growth curves that characterize the growth of an individual or a population. Such growth curves also eliminate certain temporary environmental effects that cause fluctuations in growth, thereby facilitating growth rate predictions for these animals (Blasco and Varona, 1999).
The growth curve models are characterized by a few parameters with biological interpretations; these parameters include body weight at maturity, or asymptotic body weight (A), and the index of relative growth until maturity weight is reached, known as the maturity index (k). The Richards model (Richards, 1959) is considered to be the most general of the biological equations. This model has a variable position for the inflection point for growth; however, its use is not particularly widespread due to the difficulty in fitting one of its parameters (M). The models proposed by Brody (Brody, 1945) and von Bertalanffy (Bertalanffy, 1957) are incidental cases of the Richards model; in the Brody curve, the M parameter takes the constant value of 1 , while in the Bertalanffy model, this value is 3 . The utilization of the Logistic curve (Nelder, 1961) is also generalized, as is the Gompertz model (Gompertz, 1925). With respect to this last model, Laird et al. (1965) propose a variation that estimates the rate of the decrease in weight gain based on the initial live weight and the inflection point of the growth.

The objective of this project was to describe and predict the weight of male bovine cattle of the Brahman breed that were castrated at birth and raised in their natural environment in the extensive system of the Llano Venezolano. The study focused on the season (dry or rainy) when the animals were born, utilizing different biological growth models.

\section{Materials and methods}

The study was carried out at the Hacienda Campo Alegre, which is located in the Estado Barinas, Pedraza region (Venezuela) in the Andean piedmont region of the Llanos Venezolanos.

\section{Animals and management}

Between 2003 and 2008, the weights of 1,478 males of the Brahman breed, castrated at birth, were recorded from birth until 33 months of age. 
Of these bulls, 750 were born in June and July (the rainy season) and 728 were born in January and February (the dry season).

Prior to the moment of weaning (8 months), the calves remained with their mothers in a free-range environment, using natural pastures. During the growth period (from 8 to 24 months), the animals were fed using a rotational grazing system with fresh forage composed of Brachiaria decumbens, Brachiaria humidicola and blocks of urea ad libitum in 5-ha lots (10 animals/ha). The animals remained in each lot for two days, after which the lot was allowed to rest for 28 days. All the lots had tanks that supplied water ad libitum and a covered rest area. During the fattening period, which lasted until 33 months when the animals reached $500 \mathrm{~kg}$ and were sent for slaughter, a dietary supplement in the form of feed (Table 1) administered at a rate of $1 \mathrm{~kg}$ of feed for each 100 $\mathrm{kg}$ of body weight was added as a complement to the same type of pasture that was used in the growth stage.

Table 1. Dry material composition of the feed used as a dietary supplement during the fattening stage.

\begin{tabular}{lc}
\hline Ingredient & Composition (\%) \\
\hline Soy cake & 29 \\
Whole-grain corn & 35 \\
Corn flour & 10 \\
Cane molasses & 10 \\
Yacija $^{1}$ & 15 \\
${\text { Mineral-vitamin } \text { mix }^{2}}^{2}$ & 1 \\
\hline
\end{tabular}

${ }^{1} \mathrm{~A}$ sub product of the poultry industry, this fodder contains rice hulls, wood shavings, food concentrates, etc.

${ }^{2}$ The mineral-vitamin mix provided (per $\mathrm{kg}$ of premix): $\mathrm{Zn}, 5,000 \mathrm{mg}$; Mn, 5,000 mg; Fe, $1750 \mathrm{mg}$; Co, $100 \mathrm{mg}$; I, 70 mg; Se, 25 mg; vitamin A, 600,000 IU; vitamin D3, 120,000 IU; vitamin E, 2,000 mg.

At birth, the corresponding weights and dates were recorded, and the season of birth (dry or rainy) was identified. Before weaning (8 months), the animals were weighed once a month. During the growth stage (up to 24 months), the animals were weighed once every four months. During the fattening period and until the end of the study
(33 months of age), the animals were weighed once every three months. The average daily gain of weight (ADGW) was calculated between two consecutive weighings.

Castration was carried out at the moment of birth by placing a rubber band on the upper part of the testicles, thereby causing the elimination of the necrotized scrotal sack at around one month of age.

\section{Statistical analysis}

The individual weights of the animals and their ADGW in terms of the season of birth were analyzed using the SPSS 11.5 (SPSS, base 11.5 for windows user's guide. Chiagto IL, USA). General linear model (GLM) procedure. The statistical significance of the differences was determined by the t-test. The statistical model utilized was:

$\mathrm{Y}_{\mathrm{ij}}=\mu+\mathrm{B}_{\mathrm{i}}+\mathrm{e}_{\mathrm{ij}}$

where:

$\mathrm{Y}_{\mathrm{ij}}$ : observations (body weights; ADGWs)

$\mu$ : general mean

$\mathrm{B}_{\mathrm{i}}$ : fixed effect of the birth season $(\mathrm{i}=1$, dry season; $i=2$, rainy season)

$\mathrm{e}_{\mathrm{ij}}$ : random residual effect, $\mathrm{e}_{\mathrm{ij}} \sim \mathrm{N}\left(0, \sigma^{2}\right)$.

The 23,648 weights were fitted to the models (Table 2) by applying the nonlinear regression procedure in the SPSS 11.5 (SPSS, 2002) software package. To compare the accuracy of the different equations, the following indicators suggested by Draper and Smith (1998) were considered: a determination coefficient adjusted for the number of parameters $\left(\mathrm{R}_{\text {Adj }}^{2}\right)$, which expresses the percentage variation in weight as explained by its dependence on age; the residual mean square (RMS), which indicates the variation that is not explained by the equation; and the comparison between the observed weights and those estimated by the different equations. 
Table 2. Growth models utilized to describe and predict the growth of male bovine cattle of the Brahman breed.

\begin{tabular}{ll}
\hline Growth model & Equation \\
\hline Gompertz (Laird, 1965) & W $=\mathrm{A} \exp \left(-\mathrm{b} \exp ^{-\mathrm{kt}}\right)$ \\
Brody (Brody, 1945) & $\mathrm{W}=\mathrm{A}\left(1-\mathrm{b} \exp ^{-\mathrm{kt}}\right)$ \\
Logistic (Nelder, 1961) & $\mathrm{W}=\mathrm{A}\left(1+\mathrm{b} \exp ^{-\mathrm{kt}}\right)^{-1}$ \\
Bertalanffy (Bertalanffy, 1957) & $\mathrm{W}=\mathrm{A}\left(1-\mathrm{b} \exp ^{-\mathrm{kt}}\right)^{3}$ \\
Richards (Richards, 1959) & $\mathrm{W}=\mathrm{A}\left(1-\mathrm{b} \exp ^{-\mathrm{kt}}\right)^{\mathrm{M}}$ \\
\hline
\end{tabular}

$\mathrm{W}$ : body weight $(\mathrm{kg})$. A: body weight at maturity or asymptotic body weight $(\mathrm{kg})$. b: integration constant. k: relative maturation rate $\left(\right.$ days $\left.^{-1}\right)$. M: inflection parameter. t: age (days).

\section{Results}

As observed in Table 3, the time of year when the animals were born (dry or rainy season) did not have an effect on birth weight, although at one month of age, animals born in the dry season were observed to be heavier. At 8 months, when the animals were weaned, animals born in the dry season were approximately $20 \mathrm{~kg}$ heavier than animals born in the rainy season; this was the maximum difference observed. During the growth period ( 8 to 24 months), the differences between both groups were maintained, although no differences were observed in the fattening stage (24 to 33 months). Both groups reached the proper weight for slaughter $(480-500 \mathrm{~kg})$ at similar ages. Up until the moment of weaning, the ADGW was found to be significantly higher in animals born in the dry season, while those born in the rainy season presented a higher ADGW in weeks 12, 24 and 27 ; these weeks occurred during months of greater precipitation and consequently increased pasture production. The ADGW suffered an important decrease in both birth periods that coincided with changes in handling (weaning and the beginning of the fattening period) and could be due to the stress that these processes entail.

In Table 4, the parameters for the estimates of the five biological growth curves are shown; estimates were made in terms of the birth season. For animals born in the dry season, the Brody model estimated the greatest weight at maturity $(941 \mathrm{~kg})$ and the lowest relative maturation rate (0.001 day $\left.{ }^{-1}\right)$. The Logistic curve estimated the lowest weight at maturity $(530 \mathrm{~kg})$ with the highest rate of relative maturation $\left(0.005\right.$ day $\left.^{-1}\right)$, while the other three models estimated intermediate

Table 3. Means and standard errors of body weights and average daily gains (ADGW) in terms of the time of birth.

\begin{tabular}{lccccc}
\hline & \multicolumn{2}{c}{ Dry season } & & \multicolumn{2}{c}{ Rainy season } \\
\cline { 2 - 3 } \cline { 5 - 6 } Age (months) & Weight $(\mathrm{kg})$ & ADGW $(\mathrm{g})$ & & Weight $(\mathrm{kg})$ & ADGW $(\mathrm{g})$ \\
\hline 0 & $33.16 \pm 3.60$ & - & & $33.28 \pm 3.86$ & - \\
1 & $52.35 \mathrm{a} \pm 3.80$ & $647.941 \pm 92.79$ & & $50.01 \mathrm{~b} \pm 4.40$ & $557.532 \pm 94.25$ \\
2 & $69.27 \mathrm{a} \pm 4.05$ & $571.23 \pm 82.83$ & & $66.56 \mathrm{~b} \pm 5.98$ & $551.59 \pm 43.66$ \\
3 & $83.20 \mathrm{a} \pm 5.15$ & $470.311 \pm 96.31$ & & $79.30 \mathrm{~b} \pm 9.03$ & $425.722 \pm 61.97$ \\
4 & $100.31 \mathrm{a} \pm 8.01$ & $577.621 \pm 45.08$ & & $95.53 \mathrm{~b} \pm 10.65$ & $474.422 \pm 22.03$ \\
5 & $120.84 \mathrm{a} \pm 11.40$ & $693.151 \pm 60.43$ & & $115.05 \mathrm{~b} \pm 11.31$ & $550.682 \pm 26.94$ \\
6 & $142.09 \mathrm{a} \pm 12.92$ & $717.811 \pm 46.88$ & & $133.56 \mathrm{~b} \pm 11.79$ & $616.892 \pm 56.32$ \\
7 & $165.13 \mathrm{a} \pm 16.74$ & $778.081 \pm 88.92$ & & $151.83 \mathrm{~b} \pm 16.71$ & $609.132 \pm 56.98$ \\
8 & $191.98 \mathrm{a} \pm 21.54$ & $906.841 \pm 88.98$ & & $172.59 \mathrm{~b} \pm 24.17$ & $691.782 \pm 85.32$ \\
12 & $221.83 \mathrm{a} \pm 20.43$ & $251.712 \pm 46.10$ & & $206.14 \mathrm{~b} \pm 20.12$ & $279.561 \pm 64.31$ \\
16 & $308.96 \mathrm{a} \pm 25.18$ & $735.50 \pm 56.45$ & & $296.94 \mathrm{~b} \pm 22.24$ & $756.73 \pm 48.42$ \\
20 & $391.46 \mathrm{a} \pm 25.03$ & $696.46 \pm 25.75$ & & $378.45 \mathrm{~b} \pm 24.37$ & $679.22 \pm 15.65$ \\
24 & $456.33 \mathrm{a} \pm 18.60$ & $547.602 \pm 29.90$ & & $450.93 \mathrm{~b} \pm 21.78$ & $603.121 \pm 23.68$ \\
27 & $472.42 \pm 28.62$ & $178.772 \pm 36.24$ & & $474.34 \pm 31.11$ & $261.081 \pm 56.89$ \\
30 & $492.63 \pm 27.27$ & $224.55 \pm 26.84$ & & $493.46 \pm 29.82$ & $212.44 \pm 65.55$ \\
33 & $501.71 \pm 26.16$ & $101.88 \pm 15.98$ & & $502.16 \pm 28.57$ & $98.36 \pm 45.22$ \\
\hline
\end{tabular}

Means with different letters (weight) or numbers (ADGW) are significantly different $(\mathrm{P} \leq 0.05)$. Statistical significance was determined by the t-test.

Dry season (December to April); Rainy season (May to November). 
values. Furthermore, regarding animals born in the rainy season, the greatest weight at maturity $(1,213 \mathrm{~kg})$ and the lowest rate of relative maturation $\left(0.001\right.$ day $\left.^{-1}\right)$ were estimated according to the Brody model, and the lowest weight $(535 \mathrm{~kg})$ with a higher rate of relative maturation $\left(0.005\right.$ day $\left.^{-1}\right)$ was estimated by the Logistic model.

The Brody model estimated a much higher weight at maturity for animals born in the rainy season than for those born in the dry season, while the rest of the models estimated this parameter in a similar manner regardless of birth season. No differences were found in the relative maturation rate regardless of birth season in any of the five models.

In the Richards curve, the inflection parameter (M) value was very high (94.59) in the rainy season as opposed to the dry season (4.25). This was similar to what was used consistently in both the Bertalanffy (3) and Brody (1) models.

A strikingly high value for $\mathrm{R}^{2}$ adj was found in all cases (0.98), this being only slightly lower in the Brody model for the rainy season (0.978). In both birth seasons, the highest RMS value was obtained with the Brody model. However, the lowest value for animals born in the dry season was obtained utilizing the Logistic curve, while the lowest value for animals born in the rainy season was obtained using the Gompertz model.

If we compare the real weights registered for the different controls with the weights that were estimated by the five models for the animals born in the dry season (Table 5), it can be observed that at birth $(33.16 \mathrm{~kg})$, the Brody curve estimated a lower weight $(23.84 \mathrm{~kg})$, while in the rest of the models the birth weight was overestimated, especially when using the Logistic model (59.71 $\mathrm{kg}$ ). At weaning, (8 months) the estimated weight that most closely matched the real weight (191.98 $\mathrm{kg}$ ) was found using the Brody curve (185.95 kg), and the least precise weight was obtained with the Logistic model $(164.98 \mathrm{~kg})$. At 24 months, Brody again estimated a weight that was lower than what was observed (429.20 kg estimated vs. $456.33 \mathrm{~kg}$ observed), while the Logistic model estimated more accurately $(452.15 \mathrm{~kg})$. All the models overestimated the weight at the end of the fattening period (510.10 to $529.71 \mathrm{~kg})$.

Regarding the animals born in the rainy season (Table 6), a similar phenomenon was observed in terms of the weight at birth $(33.28 \mathrm{~kg})$, with Brody underestimating this factor $(24.85 \mathrm{~kg})$ and

Table 4. Estimated parameters and standard errors for each model according to the season (rainy or dry).

\begin{tabular}{lcccccc}
\hline & $\mathrm{A}$ & $\mathrm{b}$ & $\mathrm{k}$ & $\mathrm{M}$ & $\mathrm{R} 2$ Adj & RMS \\
\cline { 2 - 7 } & & \multicolumn{2}{c}{ Dry season (December - April) } & & & \\
\hline Gompertz & $582.46 \pm 4.43$ & $2.53 \pm 0.02$ & $0.003 \pm 0.0001$ & - & 0.983 & 461.27 \\
Brody & $941.01 \pm 27.42$ & $0.98 \pm 0.01$ & $0.001 \pm 0.0001$ & - & 0.980 & 526.60 \\
Logistic & $531.60 \pm 2.80$ & $7.90 \pm 0.11$ & $0.005 \pm 0.0001$ & - & 0.981 & 517.99 \\
Bertalanffy & $623.45 \pm 6.06$ & $0.60 \pm 0.01$ & $0.002 \pm 0.0001$ & - & 0.983 & 485.35 \\
Richards & $608.81 \pm 10.83$ & $0.47 \pm 0.09$ & $0.003 \pm 0.0001$ & $4.25 \pm 1.16$ & 0.983 & 485.01 \\
Rainy season (May & November) & & & & \\
Gompertz & $601.97 \pm 5.57$ & $2.60 \pm 0.17$ & $0.003 \pm 0.0001$ & - & 0.983 & 476.38 \\
Brody & $1213.13 \pm 60.55$ & $0.98 \pm 0.01$ & $0.001 \pm 0.0001$ & - & 0.978 & 566.56 \\
Logistic & $535.30 \pm 3.05$ & $8.48 \pm 0.12$ & $0.005 \pm 0.0001$ & - & 0.981 & 490.89 \\
Bertalanffy & $658.44 \pm 8.22$ & $0.61 \pm 0.01$ & $0.002 \pm 0.0001$ & - & 0.981 & 486.66 \\
Richards & $605.28 \pm 11.76$ & $0.03 \pm 0.20$ & $0.003 \pm 0.0001$ & $94.59 \pm 6.98$ & 0.982 & 486.52 \\
\hline A: & & & & & \\
\hline
\end{tabular}

A: body weight at maturity or asymptotic body weight $(\mathrm{kg})$. b: integration constant. $\mathrm{k}$ : relative maturation rate $\left(\right.$ days $\left.{ }^{-1}\right)$. M: inflection parameter. $\mathrm{R}_{\text {Adj; }}^{2}$ adjusted determination coefficient. RMS: residual mean square. 
Table 5. Observed parameters $(\mathrm{kg}) \pm$ standard errors and estimated parameters $(\mathrm{kg})$ for each model in animals born during the dry season (December - April).

\begin{tabular}{|c|c|c|c|c|c|c|}
\hline \multirow{2}{*}{$\begin{array}{l}\text { Age } \\
\text { (months) }\end{array}$} & \multirow[b]{2}{*}{ Observed weight } & \multicolumn{5}{|c|}{ Estimated weight } \\
\hline & & Gompertz & Brody & Logistic & Bertalanffy & Richards \\
\hline 0 & $33.16 \pm 3.60$ & 46.51 & 23.84 & 59.71 & 40.06 & 42.08 \\
\hline 1 & $52.35 \pm 3.80$ & 58.15 & 45.88 & 68.65 & 53.60 & 54.97 \\
\hline 2 & $69.27 \pm 4.05$ & 71.30 & 67.38 & 78.70 & 68.70 & 69.42 \\
\hline 3 & $83.20 \pm 5.15$ & 85.85 & 88.36 & 89.93 & 85.09 & 85.23 \\
\hline 4 & $100.31 \pm 8.01$ & 101.70 & 108.84 & 102.41 & 102.55 & 102.19 \\
\hline 5 & $120.84 \pm 11.40$ & 118.66 & 128.83 & 116.17 & 120.82 & 120.08 \\
\hline 6 & $142.09 \pm 12.92$ & 136.58 & 148.34 & 131.20 & 139.70 & 138.70 \\
\hline 7 & $165.13 \pm 16.74$ & 155.27 & 167.37 & 147.49 & 158.98 & 157.84 \\
\hline 8 & $191.98 \pm 21.54$ & 174.53 & 185.95 & 164.98 & 178.46 & 177.29 \\
\hline 12 & $221.83 \pm 20.43$ & 253.43 & 255.91 & 244.03 & 255.58 & 255.05 \\
\hline 16 & $308.96 \pm 25.18$ & 327.88 & 319.38 & 327.16 & 326.54 & 327.05 \\
\hline 20 & $391.46 \pm 25.03$ & 391.70 & 376.96 & 399.29 & 387.97 & 389.15 \\
\hline 24 & $456.33 \pm 18.60$ & 442.88 & 429.20 & 452.15 & 439.07 & 440.25 \\
\hline 27 & $472.42 \pm 28.62$ & 466.24 & 462.34 & 467.26 & 462.98 & 460.4 .4 \\
\hline 30 & $492.63 \pm 27.27$ & 497.74 & 498.62 & 497.83 & 497.87 & 497.81 \\
\hline 33 & $501.71 \pm 26.16$ & 517.08 & 529.71 & 510.10 & 520.38 & 519.34 \\
\hline
\end{tabular}

all other models overestimating it. Once again, the Logistic model estimated a higher weight (56.43 kg). At 8 months (weaning), the Brody model again provided a more exact estimation of the real weight (172.51 kg estimated vs. 172.59 $\mathrm{kg}$ observed); this number was underestimated by the rest of the models (152.44 to $165.00 \mathrm{~kg}$ ). The same phenomenon occurred at 24 months (450.93 kg observed) with all of the models utilized (415.06 to $438.77 \mathrm{~kg}$ estimated). At 33 months, the Logistic model came relatively close in its estimation of the actual weight recorded (506.95 $\mathrm{kg}$ estimated vs. $502.16 \mathrm{~kg}$ observed), while the rest of the models underestimated this weight (514.01 to $525.72 \mathrm{~kg}$ ); this also occurred with the animals born in the dry season.

\section{Discussion}

The relationship between the time of year in which calves were born and their relative growth rates is of importance to meat producers of the Llano Venezolano and has been considered by such researchers as Plasse et al. (2000) and Romero et al. (2001), whose work with different breeds of bos indicus origin under tropical conditions found that animals born in the dry season were heavier at weaning, and these differences in weight later evened out at the moment of slaughter.

From our results, we can observe that although the calves were born at the same weight, the animals born in the dry season reached greater weights at weaning; this was most likely due to the decrease in disease incidence that is associated with high levels of moisture. Additionally, the high point in their lactation during the suckling period coincides with a period of greater pasture production (the rainy season). The weaning of these calves takes place at the beginning of the dry season; therefore, their weight gain at the beginning of the growth period is less than that of calves born in the rainy season. Although the growth of animals born in the rainy season prior to the moment of weaning is decreased, they are weaned at the beginning of the rainy season when pasture production is superior. Thus, they reach their peak growth during this second stage, and their weight effectively catches up to the weights of animals born in the dry season. Therefore, they reach a similar weight for slaughter during the fattening period due to compensatory growth and the use of nutritional supplements. 
Table 6. Observed parameters $(\mathrm{kg}) \pm$ standard error and estimated parameters $(\mathrm{kg})$ for each model in animals born during the rainy season (May - November).

\begin{tabular}{lcccccc}
\hline \multirow{2}{*}{$\begin{array}{l}\text { Age } \\
\text { (months) }\end{array}$} & $\begin{array}{c}\text { Observed } \\
\text { weight }\end{array}$ & Gompertz & Brody & Logistic & Bertalanffy & Richards \\
\cline { 3 - 6 } 0 & $33.28 \pm 3.86$ & 44.85 & 24.85 & 56.43 & 39.19 & 44.70 \\
1 & $50.01 \pm 4.40$ & 55.39 & 44.40 & 64.59 & 51.41 & 55.29 \\
2 & $66.56 \pm 5.98$ & 67.26 & 63.62 & 73.74 & 64.99 & 67.20 \\
3 & $79.30 \pm 9.03$ & 80.38 & 82.53 & 83.96 & 79.74 & 80.38 \\
4 & $95.53 \pm 10.65$ & 94.69 & 101.13 & 95.31 & 95.49 & 94.73 \\
5 & $115.05 \pm 11.31$ & 110.06 & 119.42 & 107.82 & 112.06 & 110.14 \\
6 & $133.56 \pm 11.79$ & 126.38 & 137.41 & 121.52 & 129.27 & 126.48 \\
7 & $151.83 \pm 16.71$ & 143.49 & 155.10 & 136.40 & 146.97 & 143.62 \\
8 & $172.59 \pm 24.17$ & 161.24 & 172.51 & 152.44 & 165.00 & 161.38 \\
12 & $206.14 \pm 20.12$ & 235.54 & 239.31 & 226.21 & 237.93 & 235.68 \\
16 & $296.94 \pm 22.24$ & 308.58 & 301.82 & 307.05 & 307.65 & 308.59 \\
20 & $378.45 \pm 24.37$ & 374.01 & 360.31 & 381.16 & 370.49 & 373.94 \\
24 & $450.93 \pm 21.78$ & 428.91 & 415.06 & 438.77 & 424.95 & 428.81 \\
27 & $474.34 \pm 31.11$ & 478.93 & 454.25 & 466.34 & 465.96 & 481.67 \\
30 & $493.46 \pm 29.82$ & 491.01 & 490.65 & 491.87 & 490.78 & 491.02 \\
33 & $502.16 \pm 28.57$ & 514.01 & 525.72 & 506.95 & 517.17 & 514.12 \\
\hline
\end{tabular}

The animals born during the rainy season presented a more irregular growth pattern, later having to make up all of the weight not gained before weaning. Brisbin et al. (1987) showed that the $\mathrm{M}$ parameter of the Richards model varies in response to environmental changes and can be used to study the effects of environmental stress on growth. This may explain the high estimated value (94.59) for births in the rainy season as opposed to animals born in the dry season (4.25).

A review of the different projects examining the growth of animals of bos indicus origin uncovered work on the Brahman breed that was performed by Menchaca et al. (1996). These authors analyzed the effects of various factors on growth in three different stages (birth to weaning, weaning to 32 months, and 32 months to maturity). They discovered that the birth season was highly significant in the first two stages, although it had no influence on growth during the third stage, which is in agreement with our findings. Pereda et al. (2005) adjusted the birth weights for this breed to the Richards curve at 120, 205 and 265 days of age in both males and females, which demonstrated that both sex and birth season have a significant influence on growth.

Silva et al. (2004) studied the influence of nongenetic factors on the growth rate in beef cattle of the Nelore breed, and they adjusted the growth data to the Brody, Gompertz, Bertalanffy, Richards and Logistic models. They concluded that the model proposed by Gompertz best estimated the growth curve. Furthermore, they discovered that among the non-genetic productive parameters, the birth season had the greatest influence on growth in animals of the Nelore breed, and they demonstrated the existence of highly significant differences $(\mathrm{P} \leq 0.01)$ among the experimental groups. Also working with the Nelore breed, Forni et al. (2009) found that the Gompertz, Brody and Bertalanffy models were adequate for estimating the weight at maturity of the animals studied. However, in a global sense, it was Brody's equation that held the closest approximation and that more adequately predicted the weight at birth. Giolo et al. (2009) found that the Logistic curve provided a close approximation for this same breed. 
When comparing the same five biological models in the Guzerá breed, Oliveira et al. (2000) found that although the Brody, Gompertz and Logistic models provided accurate estimations for the growth parameters, it was the Bertalanffy model that best estimated and predicted the growth of these animals raised under tropical conditions. We encountered computational difficulties when using the Richards model to adjust the data.

With respect to the growth rate for different breeds of bos taurus origin, which are more widely studied because they are used for beef production on a worldwide scale, we refer primarily to the different studies carried out with autochthonous Spanish breeds raised under extensive conditions and fed using a free-range system. Berlanga et al. (1995) worked with calves of the Retinta breed from birth until weaning and concluded that a close approximation could be observed using the Gompertz model, except in the first and last stages when the early weights were overestimated and the later weights were underestimated. More recently, Azor et al. (2005) compared the estimations of different curves using the Retinta breed and observed that the Gompertz curve had the best global accuracy, while the Richards model provided the least adequate approximation.

Igarzabal et al. (2005) evaluated the growth rate in calves from the Pirenaica, Blonda and Limousine breeds, utilizing the Brody, Gompertz, and Bertalanffy models and the Logistic and Quadratic functions. They observed that the Brody equation best estimated the growth in the Pirenaica and Blonda breeds, and it presented a growth rhythm that was exponential and decreased with time. The Gompertz model offered the closest estimation for the Limousine breed because their birth weight was slightly inferior to that of the other two breeds studied (which also occurs in the Brahman breed used in our study); thus, the Limousine growth pattern is best fit to a sigmoid pattern with an inflection point at approximately 150 days of age.

Abreu et al. (2004) evaluated the use of nonlineal models using both females and males of the Pantaneira breed from birth up until 27 months of age that were raised under tropical conditions. The observed weights approach the mathematical models proposed by Bertalanffy, Brody, Logistic and Gompertz. As was shown in our study, there was a high degree of discrepancy between the estimated weights at maturity, which varied from $256 \mathrm{~kg}$ in the Logistic model to 454 $\mathrm{kg}$ in the Brody model. However, in terms of the weights at weaning, the estimates made by the Brody model and the Gompertz model came closest to the actual weights observed for males and females, respectively.

A birth in the rainy season (May to November) or in the dry season (December to April) has an influence on the growth rate of Brahman calves raised under an intensive regimen on the Llano Venezolano. Although no differences in weight at birth or at slaughter are noticed, the animals born in the dry season are heavier up until the moment of weaning than animals born in the rainy season; thus, animals born in the rainy season must recover that weight during the growing and fattening stages. These animals present a greater ADGW, coinciding with periods of greater rainfall and therefore more pasture availability. Mathematical models for growth allow us to establish and predict the growth of the animals regardless of other environmental factors that could condition their progress. In this case study, the Brody model best estimated the animals' weights, coming closer to the weights actually observed. The Gompertz model demonstrated the best approximation $\left(\mathrm{R}^{2}\right.$ adj and $\left.\mathrm{RMS}\right)$. 


\title{
Resumen
}

\begin{abstract}
J.A. Miguel, S.J. Melendez, B. Asenjo, L.M. Bonilla y J. Ciria. 2012. Modelización del crecimiento de machos Brahman castrados, criados en condiciones tropicales en función de su época de nacimiento. Cien. Inv. Agr. 39(2): 279-288. En este trabajo, se presentan los parámetros que describen el crecimiento de machos de raza Brahman, castrados al nacimiento y criados en su propio ambiente en sistema intensivo en el Llano Venezolano, en función de la época de nacimiento (seca o lluviosa). Se registraron datos de pesos de 1.478 machos castrados al nacimiento de raza Brahman, 750 nacidos entre los meses de junio y julio (época de lluvia) y 728 nacidos entre los meses de enero y febrero (época de sequia). Los animales nacidos en época seca presentaron mayores pesos hasta el comienzo del cebo, coincidiendo la mayor ganancia media diaria de peso tras el destete para ambas épocas de nacimiento, con los periodos lluviosos cuando la producción de pastos era superior. Al comparar los pesos reales observados con los estimados por los diferentes modelos, se encontró que el modelo de Brody fue el que se aproximó más en su estimación al peso al nacimiento, al destete y a la madurez de los animales, en ambas épocas de nacimiento. Los modelos de Gompertz, Bertalanffy, Richards y el Logístico, sobrestimaron el peso al nacimiento y al final del cebo, y subestimaron los pesos al destete y a la madurez, en ambas épocas de nacimiento. En función de la época de nacimiento, no se encontraron diferencias en la tasa de maduración estimada para ninguno de los modelos, aunque sí hubo diferencias entre los modelos para la misma época de nacimiento.
\end{abstract}

Palabras clave: curvas de crecimiento, ganado Brahman, modelo de Bertalanffy, modelo de Brody, modelo de Gompertz, modelo Logístico, modelo de Richards.

\section{References}

Abreu, U.G.P., J.A. Cobuci, M.V.G.B. Da Silva, and J.R.B. Sereno. 2004. Uso de modelos no lineales para el ajuste de la curva de crecimiento de bovinos Pantaneiros. Archivos de Zootecnia 53: 367-370.

Azor, P.J., J.M., Jiménez, M. Valera, F. Salado, F. Álvarez, J.A. Pérez, and A. Molina. 2005. Determinación de la curva de crecimiento de los terneros de raza Retinta. FEAGAS 27: 66-72.

Berlanga, M.E., A. Molina, A.J. Luque, J.V. Delgado, and F. Salado. 1995. Growth curve in Retinto beef cattle from brith to weaning. Archivos de Zootecnia 44: 179-192.

Bertalanffy, L.V. 1957. Quantitative laws in metabolism and growth. Quarterly Review of Biology, Chicago 32: 217-230.

Blasco, A., and L. Varona. 1999. Ajuste y comparación de curvas de crecimiento. ITEA 95: 131142 .
Brisbin, I.J., C.T. Collins, G.C. White, and D.A. Mccallum. 1987. A new paradigm for the analysis and interpretation of growth data: the shape of things to come. Auk 104: 552-554.

Brody, S. 1945. Bioenergetics and growth. New York, Reinhold. 1023 pp.

Draper, N.D., and H. Smith. 1998. Applied regression analysis. New York. John Wiley and Sons. $706 \mathrm{pp}$.

Forni, S., M. Piles, A. Blasco, L. Varona, H.N. Oliveira, R.B. Lobo, and L.G. Albuquerque. 2009. Comparison of different nonlinear functions to describe Nelore cattle growth. Journal of Animal Science 87: 496-506.

Giolo, S.R., R. Henderson, and C.G.B. Demetrio. 2009. Mixed-effects growth curves in the evaluation of Nelore Sires. Scientia Agricola 66: 84-89.

Gompertz, B. 1925. On the nature of the function expressive of the law of human mortality, and on new method of determining the value of life contingencies. Phil. Trans. Royal Soc. 115: 513-585. 
Igarzabal, A., L.M., Oregui, N. Mandaluniz, M.E. Amenabar, R. Ruiz, and A.B. Neiker. 2005. Estudio de las curvas de crecimiento del ganado vacuno en los principales sistemas de producción del País Vasco. ITEA 26: 222-224.

Laird, A.K., S.A. Tyler, and A.D. Barton. 1965. Dynamics of normal growth. Growth 29: 233-248.

Menchaca, M.A., C.C. Chace, T.A. Olso, and A.C. Hammond. 1996. Evaluation of growth curves of Brahman cattle of various frame sizes. Journal of Animal Science 74: 2140-2151.

Miguel, J.A., S.J. Melendez, B. Asenjo, J.L. Calvo, J. De la Fuente, and J. Ciria. 2010. Relationship between the Venezuela and EU classification systems bovine carcasses for Brahman castrated male tropical conditions-bred. Effect of the time of birth. ITEA 106: 245-255.

Nelder, J.A. 1961. The fitting of generalization of the logistic curve. Biometrics, Washington. 17: 89-100.

Oliveira, H.N., R.B. Lobo, and C.S. Peraira. 2000. Comparação de modelos não-lineares para descrever o crescimento de fêmeas de raça Guzerá. Pesquisa Agropecuária Brasileira 35: 1843-1851.
Pereda, M.E., S.S. Gonzalez, E. Arjona, G. Bueno, and G.D. Mendoza. 2005. Adjustment of growth models and estimate of nutritional requirements for Brahman cattle in Tamaulipas, Mexico. Agrociencia 39: 19-27.

Plasse, D., H. Fossi, R. Hoogesteijn, O. Verde, C. Rodríguez, and R. Rodríguez. 2000. Producción de vacas F1 Bos taurus $\mathrm{x}$ Brahman, apareadas con toros Brahman y de vacas Brahman con toros F1 Bos taurus $\mathrm{x}$ Brahman versus Brahman. Edit. Universidad Central de Venezuela, Venezuela. 125 pp.

Richards, F.J. 1959. A flexible growth function for empirical use. Journal of Experimental Botany, Oxford 10: 290-300.

Romero, R., D. Plasse, O. Verde, R. Hoogesteijn, P. Bastidas, and R. Rodriguez. 2001. Absorción de Brahman a Guzerá y Nelore en pasto mejorado. Livestock Research for Rural Development 13: 138-154.

Silva, N.A.M. Da, L.H. De Aquino, F.F. Silva, and A.I.G. De Oliveira. 2004. Growth curves and non-genetic factors affecting growth rate of Nelore cattle. Ciencia Agrotecnica, Lavras 28: 647-654. 